\title{
HAQÎQÎ- MAJÂZî \\ (Teori dan Aplikasi Istinbâth Hukum Islam)
}

\author{
Achmad Mulyadi \\ (Jurusan Syâri'ah STAIN Pamekasan dan Alumni S2 IAIN Sunan Kalijaga \\ Yogyakarta)
}

\begin{abstract}
Abstrak
Terdapat suatu adagium para ulama bahwa nas-nas terbatas dan problem sosial senantiasa terjadi. Persoalannya adalah bagaimana teks syar'i yang terbatas tersebut dapat menyelesaikan persoalan masyarakat yang berkembang. Salah satu yang harus dilakukan adalah berijtihad atau ber-istinbâth baik dengan menggunakan pendekatan kebahasaan, pendekatan makna (konteks) maupun pendekatan singkronistik. Tulisan ini secara deskriptif analitis berusaha mengelaborasi metode istinbâth hukum Islam dengan mengkaji konsep Haqîq̂i-Majâzi. Kalangan ulama berbeda pendapat dalam penggunaan konsep keduanya, apakah suatu kata dapat digunakan dengan dua makna sekaligus atau tidak. Perbedaan tersebut disebabkan oleh sifat ungkapan majâzi yang tidak transparan. Akibat dari perdebatan tersebut mengakibatkan terjadinya perbedaan hasil istinbâth hukum.
\end{abstract}

\section{Kata Kunci:}

haqîquî, majâzi,istinbâth, dan syar'î'urfî.

\section{Pendahuluan}

Kajian tentang makna haqî̀î dan majâzî̀ (Haqîqah dan Majâz) mewarnai kajian-kajian keislaman pada abad ke $3 \mathrm{H}$, termasuk di dalamnya kajian dalam bidang hukum Islam. Pada saat itu sebagaimana yang dihadapi oleh generasi awal Islam, terdapat dua problem yang berbeda berkaitan dengan ungkapan teks, pertama, teks-teks keagamaan, khususnya yang terdapat dalam al-Qur'ân dan Sunnah sebagai sumber utama hukum Islam dan kedua, teks-teks yang 
Haqiqi-Majazi (Teori dan Aplikasi Istinbâth Hukum Islam)

bersifat non keagamaan terutama yang terdapat dalam karya-karya puisi atau sya'ir. ${ }^{1}$

Dalam perkembangan selanjutnya, selain kajian ilmu bahasa, pembahasan tentang makna haqîqî dan majâzî̀ amat berkait dengan kajian usul fiqh, terutama dalam aktifitas penggalian hukum Islam yang bersifat bayani (istinbâth hukum Islam dengan pendekatan bahasa).

\section{Haqîqah dan Majâz: Penelusuran Makna dan Penggunaannya}

Haqîqah, secara etimologis berarti sesuatu yang ditetapkan secara pasti. ${ }^{2}$ Dan secara terminologis adalah kata yang digunakan untuk menunjuk pada suatu makna sesuai dengan istilah yang digunakan.

Dilihat dari segi penggunaan kata dalam konteks pembicaraan, Haqîqah terbagi dalam beberapa macam; pertama, haqîqah lughawiyah yaitu lafaz yang digunakan untuk menunjukkan makna bahasa. ${ }^{3}$ Haqîqah lughawiyah merupakan pokok seluruh hakikat yang lain karena mula-mula lafaz digunakan untuk makna lughawî. Suatu ungkapan, yang awal mula, digunakan untuk menunjuk kepada makna bahasa yang biasa digunakan dari makna tersebut. Karena itu, jika suatu ungkapan baik berupa kata ataupun frase, maka pertama yang harus diperhatikan adalah apa arti umum bahasa tersebut. Dengan demikian, maka makna haqîqî bahasa adalah makna yang mula-mula harus kita ikuti.

Kedua, haqîqah syar'iyah yaitu lafaz yang digunakan oleh syâri'' untuk menunjuk makna bahasanya dalam konteks syara'. Ada dua syarat suatu kata digunakan untuk mengungkapkan makna haqîqah syar'îyah., yaitu makna kata tesebut ditentukan oleh syara' dan penamaan tersebut didasarkan pada istilah syara'. ${ }^{4}$ Dalam bidang muamalah tidak semua aktifitas yang tercakup dalam bidang ini, penamaan kata telah ada semenjak periode pembentukan syara'.

${ }^{1}$ Wolfhart Heinrichs, " On The Genesis of The Haqiqa-Majâz Dichotomy", Studia Islamica (1964), hlm. 112.

2 Ibrahim Anis, Al-Mu'jam al-Wasît, juz I (t.t..: Mustafa al-Bâbî al-Halabî, t.th.), hlm. 188

3 Wahbah az-Zuhaylî, Ushûl al-Fiqh al-Islâmî, juz I (Beirut: Dâr al-Fikr, t.th), hlm. 292

${ }^{4}$ Abû al-Husayn al-Bashrî, al-Mu'tamad, (t.t.: al-Maktabah al-Misriyyah lî al-Kitâb adDînîyah, t.th.), hlm. 24 


\section{Achmad Mulyadi}

Terdapat banyak hal terutama permasalahan yang muncul belakangan, yang tidak tercakup dalam penamaan ketika pembentukan syara'. Karena itu dalam hal tersebut yang lebih memungkinkan adalah penamaan makna haqîqah syar'îyah didasarkan pada analogi. Namun demikian, Abû Bakr al-Baqillanî tidak mengakui adanya haqîqah syar'îyah dengan alasan bahwa syâri' hanya menggunakan ungkapan hanya ditujukan untuk makna haqîqah lughawiyah.5 Makna salat adalah do'a, akan tetapi syâri"' menggunakan kriteria lain bahwa doa tersebut hanya bisa diterima jika memenuhi syarat-syarat tertentu.

Ketiga, haqîqah 'urfiyah yaitu kata yang digunakan dalam makna yang biasa dipakai. Haqîqah 'Urfiyah terbagi dua yaitu 'urfiyah khassah adalah lafaz yang menunjuk kepada makna tertentu yang hanya digunakan dalam komunitas tertentu. Misalnya kata qiyâs yang digunakan oleh para ahli usul fiqh menunjuk pada kegiatan menggali hukum dengan syarat-syarat tertentu dan 'urfiyah 'ammah adalah lafad yang menunjuk kepada makna yang umum yang digunakan oleh komunitas umum. Haqîqah 'urfiyah pada dasarnya adalah makna majâzî bahasa yang mempunyai kedudukan yang lebih kuat dari makna haqiqi bahasa dari lafaz tersebut seperti kata atthalâq. Menurut arti haqî̀̂̂ bahasa at-thalâq adalah melepaskan, akan tetapi maknanya berubah menjadi memutus pernikahan dan makna tersaebut yang lebih dikenal dibanding makna pertama.

Dalam hubungan antar jenis makna haqîqî sebuah kata, maka yang digunakan adalah makna haqiqi bahasa karena jika suatu kata dipakai dalam pembicaraan, makna awal ayat yang ditunjuk adalah makna haqiqi bahasa. Dengan kata lain, jika terdapat pembicaraan, maka yang mula-mula dikedepankan adalah makna leksikal bahasa tersebut.

Sedangkan Majâz, secara etimologis bermakna melewati atau melampaui ${ }^{6}$ dan secara terminologis adalah kata yang digunakan untuk menunjuk pada suatu makna yang tidak sesuai dengan istilah yang digunakan. ${ }^{7}$ Makna majâzî terbentuk karena adanya sebab

\footnotetext{
5 Shâlih 'Uhan, Asar al-Ikhtilâf fi at-Tasyîi' al-Islâmî (Kairo: Dâr al-Kutub al-Jâmi, t.th), hlm.76

${ }^{6}$ Anis, al-Mu'jam, I:147

7 Salih, Asar, hlm. 75
} 
Haqiqi-Majazi (Teori dan Aplikasi Istinbâth Hukum Islam)

tertentu yang mengharuskan seseorang mengalihkan makna dari makna yang sebenarnya kepada makna lain yang lebih tepat dan sesuai dengan konteks pembicaraan baik karena adanya qarinah mua' ayyanah maupun qarinah mani'ah. ${ }^{8}$

Makna secara majâzî terbagi menjadi tiga, yaitu pertama, majâzî lughawî adalah penggunaan lafdz bukan untuk makna asli karena adanya qarinah lughawîyah yang menyebabkan bahwa kata tersebut harus diartikan menurut arti majâzî. Kedua, majâzî syar'î adalah penggunaan lafdz bukan untuk makna asli karena adanya qarinah syar'î. Ketiga, majâzî 'urfî. Majâzî terakhir ini terbagi dalam majâzî urfi khâsh yaitu penggunaan lafaz bukan untuk makna asli karena adanya qarinah yang menunjuk kepada makna tertentu yang hanya digunakan oleh komunitas tertentu, misalnya penggunaan kata al-hâl dalam komunitas ahli bahasa arab digunakan untuk menunjuk kata yang berfungsi menjelaskan keadaan dan kondisi dan majâzî urfi amm yaitu penggunaan lafaz bukan untuk makna asli karena terdapat qarinah yang menunjuk kepada suatu makna dan berlaku secara umum, seperti penggunaan kata al-asad untuk orang pemberani. Dalam ungkapan yang bersifat majâzî ini terdapat perbedaan pendapat, Hanafîyah menyatakan bahwa jika ungkapan majâzî diungkapkan dengan lafaz umum maka majâz tersebut bersifat umum sebagaimana ungkapan haqîq $\hat{\imath}$ karena tidak adanya qarinah yang menghalanginya. Sedangkan sebagian Syâfi'îyah berpendapat bahwa majâzî dengan lafdz umumpun tidak bersifat umum karena dalalah majâz bersifat pasti. ${ }^{9}$

\section{Hubungan Antara Haqîqûi dan Majâzî̀}

Pada dasarnya suatu kalimat mempunyai makna haqîqî. Namun karena adanya sustu sebab, maka suatu kalimat itu dapat mempunyai makna lain misalnya dalam bahasa syara'. Bahwa terdapat makna majâzî yang digunakan untuk menyebut suatu perintah atau larangan. Kata-kata yang digunakan syâri' dalam bentuk majâz lughawi, kemudian menjadi terkenal, maka kemudian menjadi makna haqîqî secara syar'î. Kata as-shalâh, secara bahasa mempunyai arti do'a. dalam istilah syara' digunakan untuk menyebut salah satu bentuk

\footnotetext{
8 Wahbah az-Zuhaili, Ushûl., I: 297-299

${ }^{9}$ Wahbah az-Zuhaili, Ushîl Figh al-Islâmî, juz I(Beirut; Dâr al-Fikr, t.th.), hlm. 305
} 


\section{Achmad Mulyadi}

perintah yang dikerjakan dengan syarat dan rukun tertentu dan menjadi kata haqî $\hat{\imath}$ secara syar' ${ }^{\prime} .{ }^{10}$

Jika terdapat suatu ungkapan mempunyai dua makna sekaligus, makna haqîq $\hat{\imath}$ dan makna majâzî, ulama Hanafîyah dan Mutakallimun berpendapat bahwa lafaz tersebut tidak boleh digunakan untuk menggunakan dua makna tersebut dalam saat yang sama, karena keduanya mempunyai status yang berbeda seperti kata lamasa dalam ayat tentang hal yang membatalkan wudu' harus diartikan dengan aljima', bukan menyentuh dengan tangan karena makna inilah yang disepakati, kata tersebut juga tidak dapat diartikan keduanya.

Sedangkan ulama Syâfi'îyah dan para ahli hadis menyatakan bahwa baik makna haqîqî ataupun makna majâzî̀ dapat digunakan dalam waktu yang sama. Pada kasus di atas, ayat tersebut dapat diartikan keduanya, yaitu menyentuh dengan tangan ataupun aljima'. Ataupun juga diartikan salah satu dari keduanya (makna majâz). ${ }^{11}$ Akan tetapi suatu kata hanya dapat diartikan secara majâzî jika pemaknaan tersebut menjadi lebih jelas dan harus ada qarinah tertentu. Proses pemaknaan ini dilakukan secara berulang-ulang sehingga jika kata tersebut diucapkan tanpa penyebutan qarinahnya, maka diketahui bahwa yang dimaksud ungkapan tersebut adalah makna majâzzî bukan makna haqîqînya, ${ }^{12}$ dan harus juga mendapat legitimasi dari orang-orang yang mempunyai otoritas dalam bidangnya. ${ }^{13}$

Kaidah seperti di atas juga berlaku pada kata atau ungkapan yang bersifat non-syar'î. Jika terjadi ketidakjelasan pada suatu arti kata, apakah termasuk harus diartikan secara syar'î atau tidak, maka kata tersebut diartikan dengan makna bahasa. Inilah prinsip yang digunakan oleh para ahli hukum (fuqaha) dalam menentukan hukum muamalat.

Jika suatu kata mengandung makna haqî $q \hat{\imath}$ dan makna majâzî, maka makna yang didahulukan adalah makna haqîq $\hat{\imath}$, karena makna majâzî merupakan pengalihan dari makna haqîqî. Namun demikian, penggunaan makna haqîq $\hat{\imath}$ tidak boleh digunakan lagi ketika makna

10 Ibid, hlm. 76

11 Ibid, hlm. 305

12 Jawad Mughniyah, Ushûl al-Figh (Beirut: Dâr al-'Ilmi li al-Malâyîn, t.th.), hlm.23

13 Al-Syatibî, al-Muwafaqat,Juz III (Makkah: Dâr al-Baz lî an-Nasyr wa at-Tawzî', t.th.), hlm. 101. 
Haqiqi-Majazi (Teori dan Aplikasi Istinbâth Hukum Islam)

haqî̀î tersebut jarang digunakan baik secara logika maupun kebiasaan. ${ }^{14}$

\section{Kontroversi Penggunaan Ungkapan Majâzî}

Tidak dapat dibantah bahwa dalam setiap bahasa termasuk bahasa arab sebagai bahasa al-Qur'ân dan as-Sunnah mengenal dua bentuk kata haqîq $\hat{\imath}$ dan majâzî. Pengunaan kata haqî qî dalam al-Qur'ân dan as-Sunnah adalah hal yang pasti. Namun penggunaan kata majâzî̀ tidak ada kesepakatan di kalangan ulama. Tidak adanya kesepakatan ini disebabkan sifat pengungkapan secara majâzî bahwa ungkapan tersebut tidak sesuai dengan makna orisinal kata.

Memang al-Qur'ân mempunyai susunan yang berbeda dengan susunan yang ada ketika al-Qur'ân diturunkan dalam arti bahwa gaya susunannya bukanlah puisi dan prosa. Namun pada sisi lain, para ahli dalam memahami al-Qur'ân menelusuri dan mempelajari penggunaan kosa kata dan ungkapan yang digunakan oleh sukusuku yang ada. Hal ini menunjukkan bahwa pemahaman al-Qur'ân tidak terlepas dari pemahaman kosa kata yang digunakan oleh orang Arab pada masa turunnya al-Qur'ân. ${ }^{15}$

Istilah al-haqîqah-al-Majâz sendiri sebagai istilah yang berpasangan mulai muncul awal abad ke $3 \mathrm{H}$. Para sahabat dan para pendiri mazhab seperti Abû Hanifah, Imam Mâlik ataupun as-Syâfi'î tidak menggunakan keduanya. ${ }^{16}$ Orang yang pertama yang mengenalkan istilah al-Majâz sebagai lawan dari al-Haqîqah adalah Abu Ubaidah Mu'ammar bin al-Mustafa (w. 209 H) bahkan menjadi judul karyanya, Majâz al-Qur'ân. Namun penafsiran tentang ungkapan ayat-ayat dengan makna lain telah berlangsung jauh sebelumnya, Ibnu Abbas misalnya mengartikan kata kursî dengan ilmu dan kata ar-rafats, al-mass, dengan kata jimâ'. ${ }^{17}$

Sekalipun demikian tentang penggunaan majâz dalam al-Qur'ân dan as-Sunnah, tidak ada kesepakatan di kalangan ulama. Jumhur

14 Ibid., hlm 30

${ }^{15}$ Quraish Shihab, Kontekstualisasi Doktrin Islam dalam Sejarah, Budi Munawar Rahman (ed.) (Jakarta: Paramadina, 1995), hlm.2

${ }_{16}$ Ibnu Taimiyah, Kitâb al-Iman (Kairo: Khanji, 1907), hlm. 34.

${ }_{17}$ Nasr Hamid Abû Zayd, al-Ittijah al-Aqli fi at-Tafsir (t.t.; al-Markâz as-Saqafî al-Arabî, 1996), hlm. 93. 


\section{Achmad Mulyadi}

ulama berpendapat bahwa banyak terdapat kata atau frasa dalam alQur'ân dan as-Sunnah yang mempunyai makna majâzî, alasannya adalah terdapat ayat-ayat al-Qur'ân dan as-Sunnah yang menunjukkan arti majâzî.

Sedangkan Daud az-Dhâhirî berpendapat bahwa tidak mungkin terdapat kata majâzî dalam al-Qur'ân dan as-Sunnah. Para pengikut mazhabnya mensyaratkan kecuali jika pengertian yang ditetapkan tersebut telah populer di kalangan Arab semasa turunnya al-Qur'ân dan terdapat petunjuk yang jelas. ${ }^{18}$ Alasan mereka adalah pertama; kata majâzî̀ akan memperpanjang ungkapan tanpa guna dan mengakibatkan adanya kerancuan makna, kedua, jika Allah menggunakan kata majâzî̀ maka pasti akan dikatakan dengan ungkapan majâzẑ, ketiga, ungkapan yang bersifat majâzz adalah suatu kebohongan karena pengungkapan makna tidak menunjuk kepada makna asli, sedangkan Allah dan Rasulnya tidak mungkin melakukan kebohongan. ${ }^{19}$

Jumhur menolak keberatan yang disampaikan oleh kelompok Dzahirî. Menurut mereka ungkapan majâzî̀ mempunyai manfaat, antara lain : pertama, lafaz haqîqî sulit diucapkan dan diungkap maknanya, kedua, makna majâzî̀ akan dapat menghasilkan makna yang lebih tepat misalnya dalam mengungkapkan kondisi manusia sekalipun dalam bentuk yang fushah (jelas), ketiga, makna majâzî akan mengandung unsur memperluas makna ungkapan dan keempat maksud yang terkandung dalam makna majâzî akan lebih tegas dan kuat. ${ }^{20}$

Namun demikian dalam ungkapan majâzî terdapat beberapa pesoalan; pertama; ayat-ayat al-Qur'ân tidak mustahil menunjukkan pada makna kata asli, atau ungkapan asalnya secara bahasa bersifat majâzî, namun kemudian digunakan oleh syâri' arti haqî $\hat{\imath}$ secara syar'î, maka tidak lagi menjadi kata majâzî tetapi bersifat haqiqi syar'î seperti kata salat dan zakat, walaupun secara bahasa berarti do'a dan bersih, namun ketika berbicara dalam konteks syara' sekalipun tidak menyebut qarinahnya orang telah paham

\footnotetext{
18 Abû Zahrah, Ibnu Hazm: Hayatuh wa Asruh (Kairo: Dâr al-Fikr, t.th.), hlm.226.

${ }^{19}$ Ibnu Hazm, al-Ihkâm fî Ushûl al-Ahkâm, Juz I (Beirut: Dâr al-Kutub al-'Ilmiyyah, t.t.), hlm. 448.

${ }^{20}$ Nasr Hamid Abû Zayd, Mafhûm an-Nash (t.t.; al-Hay'ah al-Misriyyah al-Ammah lî al-Kitâb, 1993), hlm. 177.
} 
Haqiqi-Majazi (Teori dan Aplikasi Istinbâth Hukum Islam)

bahwa yang dimaksud adalah bagian dari rukun Islam. Kedua, ungkapan dalam bentuk majâzî tidak menyatakan kandungan arti secara langsung. Hal ini berarti bahwa ungkapan al-Quran memerlukan interpretasi lebih lanjut karena tidak langsung dipahami maksudnya. Selain itu, pemindahan makna dari makna haqîq $\hat{\imath}$ kepada makna majzi melemahkan makna haqîqî. Dan tidak mustahil pemaknaan tersebut menjadi sulit dicari karena harus mencari qarinah terlebih dahulu. Ketiga, jika ungkapan dalam al-Quran menggunakan bentuk majâzî, maka seharusnya salah satu dari sifatsifat Allah adalah al-Mutajawwiz. ${ }^{21}$

Terhadap keberatan-keberatan tersebut, al-Bashrî menyatakan bahwa: Pertama, jika yang dimaksudkan mereka demikian, maka pemahaman para penggali syara' terhadap makna kata yang dikehendaki Allah mendahului pengetahuan mereka terhadap makna haqî $\hat{\imath}$ kata tersebut. ${ }^{22}$ Dengan kata lain, tidak mungkin bahwa sebelum ada penggunaan kata oleh syara' telah terjadi pemaknaan kata tersebut sesuai dengan maksud yang terkandung dalam arti syara'. Kedua, pendapat mereka bahwa majâz menunjukkan maknanya tidak jelas memang benar, akan tetapi jika disertai dengan syaratsyarat tertentu yaitu adanya suatu qarinah atau hubungan yang menunjukkan bahwa kata tersebut digunakan secara majâzî ungkapan tersebut menjadi jelas bahkan hal ini menjadikan ungkapan tersebut menjadi lebih jelas dan tepat. Ketiga, mensifati Allah dengan alMutajawwiz tidaklah mungkin karena kata at-tajwîz mempunyai konotasi negatif. 23

Perbedaan tersebut sebenarnya tidak semata-mata persoalan kaidah bahasa namun juga terkait dengan persoalan teologis. Ini dapat dipahami terutama dalam alasan penolak adanya penggunaan makna majâzî dalam al-Quran dan Sunnah. Namun tidk dapat dipungkiri bahwa terdapat indikasi kuat yang menunjukkan bahwa al-Quran dan Sunnah menggunakan ungkapan majâzî untuk menyampaikan maksud.

${ }^{21}$ Abû al-Husayn Al-Bashrî, al-Mu'tamad, (t.t.: al-Maktabah al-Mishrîyyah lî al-Kitâb ad-Dînîyyah, t.th.), hlm. 24

22 Ibid.

23 Ibid. 


\section{Achmad Mulyadi}

Perbedaan pendapat tersebut juga berpengaruh pula terhadap hasil istinbâth hukum yang digali dari ayat tersebut, seperti kata lamasa. Jika kata tersebut diartikan secara haqîq $\hat{\imath}$, maka dua orang berbeda jenis kelamin yang bersentuhan wuduknya batal, berbeda hasilnya dengan arti majâzî.

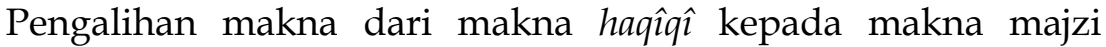

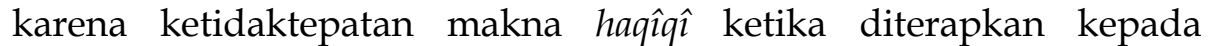
ungkapan tersebut. Namun demikian bukan berarti bahwa semua ungkapan yang tidak jelas kemudian diartikan dengan makna lain (majâzî). Terdapat beerapa syarat yang harus diperhatikan untuk menggunakan makna majâzî, yaitu: Pertama, harus ada qarinah yang menunjukkan bahwa ungkapan tersebut mengandung makna lain. Kedua, makna majâzî yang digunakan sesuai dengan kebenaran yang diakui oleh mereka yang mempunyai otoritas dalam bidangnya dan arti tersebut telah dikenal dalam bahasa arab klasik.

\section{Aplikasi Konsep dalam Konteks Perbedaan Fiqh}

Jika dikaji secara mendalam ayat-ayat dalam al-Quran dan sunnah akan ditemukan beberapa indikasi dan bukti bahwa banyak ayat-ayat al-Quran dan sunnah menggunakan yang bersifat majâzî dalam penyampaian maksudnya, baik yang berupa berita, perintah ataupun larangan. Dalam menjelaskan tentang kondisi lingkungan manusia misalnya, al-Qur'ân menyatakan dengan kata $d z u l m$ untuk

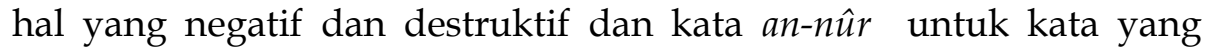
konstruktif, sekalipun juga dapat juga diartikan secara haqîqî. Jika suatu kata didukung oleh suatu dalil nas bahwa kata tersebut menunjuk kepada makna majâzî, makna kata tersebut harus diartikan dengan makna tersebut. Namun, jika tidak ada dalil yang mendukung maka harus diartikan dengan makna haqîq $\hat{\imath}^{24}$

Demikian juga ungkapan dengan menambah huruf atau kata, misalnya dalam mengungkapkan sifat Allah, al-Quran mengungkapkannya dengan ليس كمنلـه شئ. Ayat tersebut memiliki penambahan huruf kaf dan tidak mempunyai arti. Namun demikian, ada kelompok yang berpendapat bahwa huruf kaf tersebut bukanlah

\footnotetext{
${ }^{24}$ Ibnu Hazm, Juz I, al-Ihkâm, hlm., 449
} 
Haqiqi-Majazi (Teori dan Aplikasi Istinbâth Hukum Islam)

merupakan huruf tambahan, akan tetapi mempunyai arti dan ليس مثل منثله شئ mengandung maksud yang sama artinya dengan

Ungkapan ayat dapat juga dengan mengurangi huruf atau و سئل القر يه التى كنا فيهاو العير mengurangi kata-kata, seperti dalam ayat . Yang dimaksud oleh ungkapan ayat tersebut adalah "bertanyalah kepada penduduk desa dan kepada kafilah yang kami jumpai". Ibnu Hazm berpendapat bahwa ayat tersebut memungkinkan diartikan secara haqî $\hat{\imath}$, yaitu seandainya Ya'qub bertanya kepada kafilah tentang mereka atau bertanya kepada penduduk desa, niscaya akan dijawab, demikian juga dapat diartikan secara majâzî.

Selanjutnya Ibnu Hazm menyatakan bahwa kasus tersebut serupa dengan yang terdapat dalam surat al-Kahfi ayat 77 tentang perjalanan Musa dengan Hidir ketika sampai pada suatu kota, keduanya mendapati bangunan yang hendak roboh kemuadian ditegakkan kembali. فو جدا جدارا ير يد ان ينقض فاقامـ pada ayat ini diungkapkan dengan "tembok yang berkehendak". Kehendak hanya mungkin bagi mahluk yang bernyawa. Dalam ayat tersebut Allah menetapkan kehendak bagi tembok sebagai ganti dari kata al-mail. Dari beberapa ayat tersebut, menurut Ibnu Hazm, tersirat bahwa Allah mempunyai kuasa atas apa yang ia kehendaki. Hanya saja tidak mesti penetapan makna kata dengan makna lain, menunjukkan bahwa hal tersebut adalah majâzî. 25

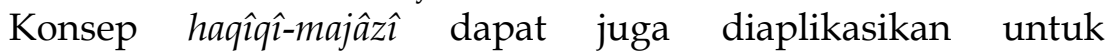
menjelaskan problem hukum dalam makna hadis, seperti hadis

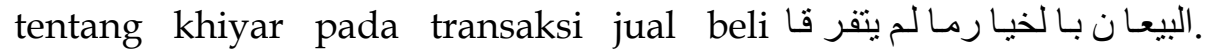
Menurut Hanafîyah dan Mâlikîyah, yang dimaksud khiyâr adalah يتفر قا tawar menawar dan ini berakhir ketika terjadi akad. Jadi kata diartikan dengan makna terjadinya akad. Demikian juga hadis tentang larangan menawar barang yang sedang ditawar orang lain. Dalam hadis tersebut terjadi pengalihan arti kata. Kata bay' diartikan dengan menawar dan kata nikah diartikan dengan khitbah.

Dari elaborasi di atas menunjukkan bahwa al-Quran dan asSunnah selain menggunakan ungkapan yang bersifat haqîq $\hat{\imath}$, juga menggunakan ungkapan majâzî. Penggunaan dua konsep tersebut

${ }^{25}$ Ibid. 
telah melahirkan perbedaan pendapat (ikhtilâf) dengan dasar dan alasan masing-masing.

\section{Penutup}

Salah satu metode istinbâth hukum adalah dengan menggunakan pendekatan bahasa (lafadz). Diantara pendekatan bahasa ini dapat dilakukan dengan memperhatikan sifat dan bentukbentuk ungkapan nas, baik ungkapan yang bersifat haqîq $\hat{\imath}$ maupun ungkapan yang bercorak majâzî̀ (metaforis).

Kalangan ulama berbeda pendapat dalam penggunaan konsep keduanya, apakah suatu kata dapat digunakan dengan dua makna sekaligus atau tidak. Perbedaan tersebut disebabkan oleh sifat ungkapan majâzî̀ yang tidak transparan. Akibat dari perdebatan tersebut mengakibatkan terjadinya perbedaan hasil istinbâth hukum. 